\title{
ANALISIS FAKTOR-FAKTOR YANG MEMPENGARUHI PRESTASI BELAJAR SISWA KELAS X SMA AL-ISLAM KRIAN
}

\author{
${ }^{1)}$ Nurul Afida \\ ${ }^{2)}$ Edy Sulistiyawan \\ ${ }^{1)}$ S1 Program Statistika, FMIPA, Universitas PGRI Adi Buana Surabaya \\ ${ }^{2)}$ Program Studi Statistika, FMIPA, Universitas PGRI Adi Buana Surabaya
}

\begin{abstract}
ABSTRAK
Kurikulum 2013 diharapkan dapat meningkatkan prestasi belajar siswa. Namun, hal ini tidak akan berdampak banyak apabila tidak ada campur tangan dari beberapa puhak, baik guru maupun lingkungan. Untuk meningkatkan prestasi belajar tentunya akan beberapa faktor yang mempengaruhi, diantaranya: disiplin belajar, peranan guru, motivasi belajar, fasilitas belajar utama, dan fasilitas belajar pendukung. Salah satu metode untuk mengidentifikasi faktor-faktor tersebut adalah analisis faktor. Rumusan dalam penelitian ini adalah "Faktor-faktor apa saja yang mempengaruhi prestasi belajar siswa kelas X SMA Al-Islam Krian?". Tujuannya adalah untuk mengetahui faktor-faktor apa saja yang mempengaruhi prestasi belajar siswa kelas X SMA Al-Islam Krian. Data diperoleh dari metode kuesioner, dengan sampel 72 orang, hasil analisis data didapatkan bahwa semua butir kuesioner adalah valid $\left(\mathrm{r}_{\text {rasio }}>\mathrm{r}_{\text {tabel }}\right)$, kuesioner adalah reliable (nilai Cronbach Alpha dari tiap butir kuesioner lebih besar dari 0,60). Hasil uji KMO and Bartlett's Test sebesar 0,687 yang berarti analisis dapat dilanjutkan. Variabel dirotasikan dengan loading faktor 0,54 sehingga membentuk 26 variabel yang layak. Dari 26 variabel membentuk 5 faktor yang mempengaruhi prestasi belajar, yaitu: disiplin belajar, peranan guru, motivasi belajar, fasilitas belajar utama, dan fasilitas belajar pendukung. Kesimpulan dari penelitian ini adalah faktor-faktor yang mempengaruhi prestasi belajar siswa kelas $\mathrm{X}$ SMA Al-Islam Krian yaitu disiplin belajar, peranan guru, motivasi belajar, fasilitas belajar utama, dan fasilitas belajar pendukung
\end{abstract}

Kata Kunci: Analisis Faktor, Prestasi Belajar, Disiplin Belajar, Peranan Guru, Motivasi Belajar, Fasilitas Belajar Utama, dan Fasilitas Belajar Pendukung

\section{Pendahuluan}

Perubahan kurikulum di tahun 2013, merupakan upaya dari pemerintah untuk memperbaiki tingkat pendidikan di Indonesia. Kurikulun KTSP dianggap masih belum dapat memperbaiki tingkat pendidikan di Indonesia. Pergantian kurikulum dilakukan dengan harapan pendidikan di Indonesia dapat lebih baik dari sebelumnya. Manfaat kurikulum 2013 terhadap prestasi belajar siswa, tetap tidak akan berdampak banyak apabila tidak ada campur tangan dari beberapa pihak, baik dari guru maupun lingkungan.

Prestasi belajar siswa merupakan suatu hal yang sangat diinginkan oleh setiap guru maupun orang tua. Seperti yang diungkapkan oleh Slameto (2010: 2) "Belajar ialah suatu proses usaha yang dilakukan seseorang untuk memperoleh suatu perubahan tingkah laku yang baru secara keseluruhan, sebagai hasil pengalamannya sendiri dalam interaksi dengan lingkungannya". 
Untuk meningkatkan prestasi belajar siswa di sekolah, banyak cara yang ditawarkan untuk membuat siswa lebih berprestasi. Salah satunya adalah tambahan bimbingan belajar. Namun, itu semua tidak terlepas dari faktor intern dan faktor ekstern. Faktor intern yang dapat mempengaruhi prestasi belajar siswa diantaranya intelegensi, motivasi, sikap, minat, bakat, dan konsentrasi. Sedangkan faktor ekstern yang dapat mempengaruhi prestasi belajar siswa diantaranya faktor keluarga, faktor sekolah, dan faktor masyarakat. Faktor sekolah meupakan faktor yang menyangkut proses pembelajaran yang diterima oleh siswa. Bukan hanya sekedar menerima materi dari guru, tetapi juga dapat dari model pembelajaran yang digunakan, fasilitas kelas, kebersihan kelas, dan lainnya.

Berangkat dari pemikiran tersebut, peneliti memilih judul "Analisis Faktor-Faktor yang Mempengaruhi Prestasi Belajar Siswa Kelas X SMA Al-Islam Krian” Tujuan dalam penelitian ini adalah untuk mengetahui variabel apa saja yang mempengaruhi prestasi belajar siswa kelas X SMA Al-Islam Krian, untuk mengetahui variabel apa saja yang dominan dalam memengaruhi prestasi belajar siswa kelas X SMA Al-Islam Krian, dan untuk mengetahui faktor apa saja yang mempengaruhi prestasi belajar siswa kelas $\mathrm{X}$ SMA Al-Islam Krian.

\section{Tinjauan Pustaka}

\subsection{Uji Validitas}

Menurut Usman dan Sobari (2013: 10) validitas merupakan pengujian yang dilakukan untuk mengukur kemampuan atribut-atribut yang digunakan dalam mengukur variabel. Rumus yang dapat digunakan untuk uji validitas konstruk adalah dengan korelasi product moment, yaitu:

$$
r_{\text {hitung }}=\frac{n \sum x y-\sum x \sum y}{n \sum x^{2} \overline{2}-\sum x \overline{2}^{2} \frac{\sum y^{2}}{\overline{2}-\sum y^{2}}}
$$

(Usman dan Sobari, 2013: 36)

Keterangan:

$n$ : jumlah responden

$x$ : skor variabel (jawaban responden)

$y$ : skor total dari variabel untuk responden ke- $n$

\subsection{Uji Reliabilitas}

Menurut Siregar (2013: 87) Reliabilitas bertujuan untuk mengetahui sejauh mana hasil pengukuran tetap konsisten, apabila dilakukan pengukuran dua kali atau lebih terhadap gejala yang sama dengan menggunakan alat pengukur yang sama pula.

\subsection{Uji Bartlett}

Menurut Usman dan Sobari (2013: 36-37) pengujian ini dilakukan untuk melihat apakah variabel yang digunakan berkorelasi dengan variabel lainnya. Jika variabel-variabel yang digunakan sama sekali tidak mempunyai korelasi dengan variabel lainnya, maka analisis faktor tidak dapat dilakukan rumus:

Pengujian dilakukan dengan menggunakan Statistik Chi Square, dengan 


$$
X_{\text {nitung }}^{2}=\sum_{i=1}^{k} \frac{o_{I}-E_{I}^{2}}{E_{I}}
$$

(Sudjana, 1996: 273)

Keterangan:

$X^{2}$ : Nilai Chi Square

$O_{I}$ : Frekuensi hasil pengamatan

$K$ : Jumlah kelas interval

Setelah menghitung Statistik Chi Square, maka langkah selanjutnya adalah mengambil keputusan. Adapun kriteria keputusan adalah, Tolak $H_{0}$, jika:

$$
x_{\text {hitung }}^{2}>x^{2} \propto, p(p-1) / 2
$$

$x_{\text {hitung }}^{2}>x^{2} \propto, p(p-1) / 2$ merupakan angka yang didapat dari tabel. Akan tetapi, untuk mengambil keputusan dalam pengolahan data menggunakan SPSS, kita tidak perlu lagi membandingkan dengan nilai tabel, sebab SPSS telah menyediakan nila 'Sig' (Level of significance).

\subsection{Uji Kaiser Mayer Oikin (KMO)}

Menurut Usman dan Sobari (2013: 38) KMO merupakan suatu uji untuk menunjukkan apakah metode sampling yang digunakan memenuhi syarat ataukah tidak, yang berimplikasi apakah data dapat dianalisis lebih lanjut menggunakan analisis faktor atau tidak.

Adapun formulasi pengujian secara sistematis dituliskan dengan:

Dengan $i=1,2,3, \ldots$, dan $j=1,2,3, \ldots$

$$
\mathrm{KMO}=\frac{\sum_{i}^{n} \sum_{j \neq i}^{n} r_{i j}^{2}}{\sum_{i}^{n} \sum_{j \neq i}^{n} r_{i j}^{2}+\sum_{i}^{n} \sum_{j \neq i}^{n} a_{i j}^{2}}
$$

(Usman dan Sobari, 2013: 36)

Keterangan:

$r_{i j}^{2}$ adalah koefisien korelasi sederhana dari variabel $i$ dan $j$.

$a_{i j}^{2}$ adalah koefisien korelasi parsial dari variabel $i$ dan $j$.

\subsection{Metode Principal Component Analysis (PCA)}

Menurut Baroroh (2013: 84) metode Principal Component Analysis (PCA) adalah suatu metode analisis yang digunakan untuk mengelompokkan beberapa variabel menjadi suatu kelompok variabel yang lebih sedikit, di mana pengelompokan ini didasarkan pada kesamaan sifat/karakteristik yang dimiliki oleh data variabel-variabel tersebut. Menurut Santoso (2012: 60) sebuah variabel akan mengelompokkan ke suatu faktor (yang terdiri atas variabel-variabel yang lainnya pula) jika variabel tersebut berkorelasi dengan sejumlah variabel lain yang masuk dalam kelompok faktor tertentu.

Varians total pada sebuah variabel dapat dibagi enjadi tiga bagian, yaitu:

a. Common variance, yakni varians yang dibagi dengan varians lainnya, atau jumlah varians yang dapat diekstrak dengan proses factoring. 
b. Spesific variance, yakni varians yang beraitan dengan variabel tertentu saja, jenis varians ini tidak dapat dijelaskan dengan korelasi hingga menjadi bagian dari variabel lain, namun varians ini masih berkaitan secara unik dengan satu variabel.

c. Error variance, yakni varians yang tidak dapat dijelaskan lewat proes korelasi, jenis ini muncul karena proses pengambilan data yang salah, pengukuran variabel yang tidak tepat dan sebagainya.

\section{METODE PENELITIAN}

Data yang digunakan pada penelitian ini adalah data primer, yang diperoleh dengan metode kuesioner. Jenis kuesioner yang digunakan dalam proses pengumpulan data terdapat dua macam, yaitu kuesioner terbuka dan kuesioner tertutup. Kuesioner diberikan kepada responden berupa pertanyaan yang berupa isian dan pernyataan dalam bentuk pilihan. Data yang telah terkumpul, akan di analisis dengan uji KMO and Bartlett's Test. Apabila nilai KMO yang di dapat lebih besar dari 0,5 maka dapat dilanjutkan pada analisis faktor. Metode yang digunakan pada analisis faktor yaitu metode Principal Component Analysis (PCA) yang kemudian dilakukan proses factoring untuk mengetahui faktor-faktor apa saja yang terbentuk.

\section{Hasil Penelitian dan Pembahasan}

\subsection{Uji Validitas}

Dapat diketahui bahwa dari 47 variabel yang telah diujikan, ternyata terdapat 4 variabel yang dikatakan tidak valid. Hal ini disebabkan karena nilai corrected item-total correlation kurang dari nilai $r$ tabel yaitu 0,235. Sehingga keempat variabel ini harus di eliminasi atau dihilangkan. Keempat variabel yang harus dihilangkan yaitu variabel 3, variabel 34, variabel 37, dan variabel 42. Dari 43 variabel yang telah diujikan ulang, ternyata seluruhnya dinyatakan valid. Hal ini disebabkan karena nilai corrected item-total correlation secara keseluruhan telah lebih dari nilai $r$ tabel yaitu 0,235

\subsection{Uji Reliabilitas}

Diketahui nilai cronbach's alpha sebesar 0,934 dengan jumlah variabel 43 . Hal ini dapat dikatakan nilai cronbach's alpha yang diperoleh lebih besar dari 0,6. Sehingga dapat disimpulkan penelitian ini reliabel.

\subsection{KMO and Bartle' Test}

Tabel 4.1 KMO and Bartlett's Test

\begin{tabular}{|ll|r|}
\hline Kaiser-Meyer-Olkin &, 687 \\
Measure of Sampling & \\
Adequacy. & \\
Bartlett's & Approx. Chi- \\
Test of & Square & \\
Sphericity & df & 9039,116 \\
& Sig. &, 000 \\
\hline
\end{tabular}


Berdasarkan tabel 4.1 diperoleh nilai KMO MSA sebesar 0,687. Nilai ini menunjukan bahwa nilai KMO MSA di atas 0,5. Hal ini menunjukkan bahwa proses analisis faktor yang dilakukan sudah tepat dan dapat dilanjutkan. Selain nilai KMO MSA, dari tabel 4.4. diperoleh nilai signifikansi sebesar 0,000. Karena nilai signifikansi yang diperoleh kurang dari alpha 5\% atau 0,05, maka dapat dikatakan bahwa terjadi korelasi yang signifikan di antara variabel yang dianalisis dan sampel (Variabel) sudah memadai untuk dianalisis lebih lanjut

\subsection{Anti Image Matrices}

Dari hasil analisis data diperoleh nilai MSA (Measure of Sampling Adequacy) pada setiap variabel di atas 0,5. Dengan kata lain, seluruh variabel mempunyai nilai MSA di atas 0,5. Sehingga dapat dikataan seluruh variabel dapat dianalisis lebih lanjut.

\subsection{Total Variance Explained}

diantaranya:

Berdasarkan analisis data diperoleh beberapa kesimpulan yang

a. Nilai eigenvalues untuk faktor 1 adalah 12.341; untuk faktor 2 adalah 3.460; dan seterusnya. Apabila dijumlahkan, ke 43 eigenvalue tersebut akan bernilai 43 (sama banyaknya dengan banyaknya variabel)

b. Besarnya varians yang dapat diterangkan oleh faktor baru yang terbentuk apabila hanya diambil 1 faktor saja adalah 28,701\%. Besarnya varians yang diterangkan oleh faktor baru yang terbentuk apabila hanya mengambil 2 faktor saja adalah $36,747 \%$. Besarnya varians yang diterangkan oleh faktor baru yang terbentuk apabila hanya mengambil 3 faktor saja adalah $42,353 \%$ dan seterusnya.

c. Secara umum banyaknya faktor yang harus diambil didasarkan dari nilai eigenvalue $>1$, sehingga dalam kasus ini hanya mengambil 5 faktor saja.

\subsection{Rotated Component Matrix}

Rotated Component Matrix memuat nilai loading faktor dari setiap variabel untuk masing-masing faktor baru yang terbentuk. Loading faktor merupakan besarnya korelasi antara faktor skor dan variabel tersebut. Dari hasil tersebut setelah dilakukan loading pembatasan bahwa hanya variabel-variabel yang memenuhi loading pembatasan bahwa hanya variabel-variabel yang memenuhi loading faktor sebesar 0,54 maka terbentuk 26 variabel yang layak serta membentuk lima faktor, yaitu: Disiplin belajar, peranan guru, motivasi belajar, fasiitas belajar utama, dan fasilitas pendukung.

\section{Simpulan}

Berdasarkan analisis yang telah dilakukan dapat diperoleh beberapa simpulan, diantaranya:

1. Variabel yang mempengaruhi prestasi belajar siswa kelas X SMA Al-Islam Krian terdapat 26 variabel, yaitu: masuk kelas tepat waktu, datang tepat waktu, memakai kelengkapan sekolah, mencari sumber yang dianjurkan guru, memberi keterangan saat tidak hadir dalam kegiatan belajar, meminta ijin kepada guru ketika meninggalkan 
pelajaran, saya mempunyai harapan dan cita-cita di masa depan, guru membantu siswa jika siswa mengalami kesulitan, guru memberikan tugas sesuai dengan materi, guru selalu menjawab pertanyaan siswa dengan benar dan memuaskan siswa, guru bersikap sopan dan santun di depan siswanya, guru mengajukan pertanyaan kepada siswa sesuai materi, guru menegur siswa jika siswa bermain di kelas, belajar tepat waktu di rumah, waktu senggang di luar jam sekolah saya manfaatkan untuk belajar, saya belajar dan mengerjakan tugas secara mandiri, dapat menyelesaikan tugas dengan cepat, saya mempunyai cara yang menarik dalam belajar. tersedia LCD dan projektor di dalam kelas, tersedia papan white board dan spidol board maker di dalam kelas, perencana jangka panjang, tersedia Televisi di dalam kelas, tersedia lab. Bahasa, guru memahami siswa, guru mendekati siswa, dan tersedia lab. Komputer

2. Variabel yang dominan dalam mempengaruhi prestasi belajar siswa Kelas X SMA AlIslam Krian, terdapat 9 variabel yaitu: masuk kelas tepat waktu, datang tepat waktu, guru membantu siswa jika siswa mengalami kesulitan, guru memberikan tugas sesuai dengan materi, belajar tepat waktu di rumah, tersedia LCD dan projektor di dalam kelas, tersedia papan white board dan spidol board maker di dalam kelas, tersedia Televisi di dalam kelas, dan tersedia lab. Bahasa,

3. Faktor-faktor yang mempengaruhi prestasi belajar siswa kelas X SMA Al-Islam Krian, yaitu: disiplin belajar, peranan guru, motivasi belajar, fasiitas belajar utama, dan fasilitas belajar pendukung.

\section{Daftar Pustaka}

Arikunto, Suharsimi. 2009. Dasar-dasar Evaluasi Pendidikan. Jakarta: PT. Bumi Aksara.

Anom. 2014. Profesi Kependidikan. http://anomsblg.wordpress.com/profesikependidikan/peran-guru-dalam-pembelajaran/2014. Tanggal Unduh 1 Agustus 2014.

Baroroh, Ali. 2013. Analisis Multivariat dan Time Series dengan SPSS 21. Jakarta: PT. Elex Media Komputindo.

Ladri, Juni. Pengaruh Motivasi Minat Belajar dan Penyediaan Fasilitas Belajar di Rumah Terhadap Hasil Belajar. http://juniladri.wordpress.com 12013/01/11/pengaruh-motivasi-minat-belajar-dan-penyediaan-fasilitasbelajar-di-rumah-terhadap-hasil-belajar-ekonomi/. Tanggal Unduh 1 Agustus 2014.

Santoso, Singgih. 2012. Aplikasi SPSS Pada Statistik Multivariat. Jakarta: PT. Elex Media Komputindo.

Siregar, Sofyan. 2013. Statistik Parametrik untuk Penelitian Kuantitatif. Jakarta: PT. Bumi Aksara.

Slameto. 2010. Belajar dan Faktor-faktor yang Mempengaruhinya. Jakarta: Rineka Cipta.

Sofyan. 2012. Laptop Fasilitas Belajar Siswa. http://kmssofyanegoblog. wordpress.com/2012/11/01/laptop-fasilitas-belajar-utama-siswa-sma/.

Tanggal Unduh 1 Agustus 2014.

Sudjana. 1996. Metode Statistika. Bandung: PT. Tarsito.

Suprijono, Agus. 2012. Cooperative Learning. Yogyakarta: Pustaka Pelajar.

Usman, Hardius dan Sobari, Nurdin. 2013. Aplikasi Teknik Multivariate untuk Riset Pemasaran. Jakarta: Rajawali Pres.

Vhasande. 2014. Disiplin Dalam Belajar. http://vhasande.blogspot.com /2014/05/disiplin-dalam-belajar.html. Tanggal Unduh 1 Agustus 2014. 